\title{
Estrogen-triggered delays in mammary gland gene expression during the estrous cycle: evidence for a novel timing system
}

\author{
Gary B Silberstein, Katharine Van Horn, Eva Hrabeta-Robinson and Jennifer Compton \\ Department of Molecular, Cell and Developmental Biology, Sinsheimer Laboratories, University of California, Santa Cruz, California 95064, USA \\ (Requests for offprints should be addressed to G B Silberstein; Email: silberstein@biology.ucsc.edu)
}

\begin{abstract}
During the estrous cycle and beginning in estrus, the mammary gland undergoes pregnancy-like development that depends on transcriptional regulation by the estrogen and progesterone receptors (ER, PR) and Pax-2 as well as the action of the growth factors Wnt-4 and RANKL. In this report, we first describe the decay and delayed expression of $\mathrm{ER} \alpha, \mathrm{PR}$, and Pax-2 proteins as well as depression of Wnt-4 and RANKL mRNA coincident with the strong estrogen surge in proestrus. In time-course studies using ovariectomized mice, a single estrogen injection replicated these delays and caused an $18 \mathrm{~h}$ delay in Wnt-4 expression. Molecular time-delay systems are at the core of cellular cycles, most notably the circadian clock, and depend on proteasome degradation of transcriptional regulators that exhibit dedicated timing functions. The cytoplasmic dynamics of these regulators govern delay duration through negative transcription/translation feedback loops. A proteasome inhibitor, PS-341, blocked estrogen-stimulated ER $\alpha$, PR, and Pax-2 decay and proteasome chymotryptic activity,
\end{abstract}

assayed using a fluorogenic substrate, was elevated in proestrus correlating with the depletion of the transcription factors. The 18-h delay in Wnt-4 induction corresponded to the turnover time of $\mathrm{Pax}-2$ protein in the cytoplasm and was eliminated in Pax-2 knockout mammary tissue, demonstrating that Pax-2 has a unique timing function. The patterns of estrogen-triggered $\mathrm{ER} \alpha, \mathrm{PR}$, and $\mathrm{Pax}-2$ turnover were consistent with a negative transcriptional feedback. Retarding the expression of $\mathrm{ER} \alpha, \mathrm{PR}$, and $\mathrm{Pax}-2$ may optimize preparations for pregnancy by coordinating expression of critical receptors and transcription factors with rising estrogen and progesterone levels in estrus. The estrogen surge in proestrus has no defined mammotropic function. This study provides the first evidence that it is a synchronizing signal triggering proteasome-dependent turnover of mammary gland ER $\alpha, \mathrm{PR}$, and Pax-2. We hypothesize that the delays reflect a previously unrecognized timing system, which is present in all ovarian target tissues.

Journal of Endocrinology (2006) 190, 225-239

\section{Introduction}

The mammalian estrous cycle is an endocrine clock that communicates time through periodic oscillations in the concentration of the ovarian steroids, estrogen and progesterone. In tissues such as the mammary gland and uterus, the estrogen and progesterone receptor (ER, PR) systems monitor hormone concentration and transduce this information into time-appropriate developmental responses. Broadly speaking, two opposing developmental phases of the estrous cycle are timed in this way. A 'preparative' phase marked by elevated estrogen and progesterone levels during estrus leaves ovarian target tissues primed for pregnancy. A second phase begins as progesterone concentrations decline in diestrus and is marked by the apoptotic destruction of the earlier preparations. By far the most dramatic endocrine feature of the estrous cycle is a strong estrogen pulse in diestrus/proestrus that defines the boundary between these two developmental phases and signals the start of a new cycle (Fig. 1A) (Schedin et al. 2000, Fata et al. 2001). In the mammary gland, estrous cycle-driven preparations for pregnancy are indistinguishable from early pregnancy as the complexity of the ductal system increases markedly in each case (Robinson et al. 1995, Liu et al. 1996, Schedin et al. 2000, Fata et al. 2001 ). This begins during estrus when small lateral branches extend off larger ducts to become the scaffolding for the morphogenesis and differentiation of milk producing alveoli (Silberstein 2001, Brennan \& Brown 2004). Recent work has shown that the development of these small branches is dependent on the growth factor Wnt-4 (Brisken et al. 2000), with alveolar growth requiring the growth factor RANKL. RANKL is the ligand for receptor activator of nuclear factor-kappaB (RANK) and is induced by progesterone (Fata et al. 2000, Brisken et al. 2002).

Pax-2 is a proto-oncogene transcription factor characterized by a paired domain and a partial homeobox. It is active during the development of kidney and central nervous system where it stimulates stem cell proliferation, 
A. Estrous Cycle Stages

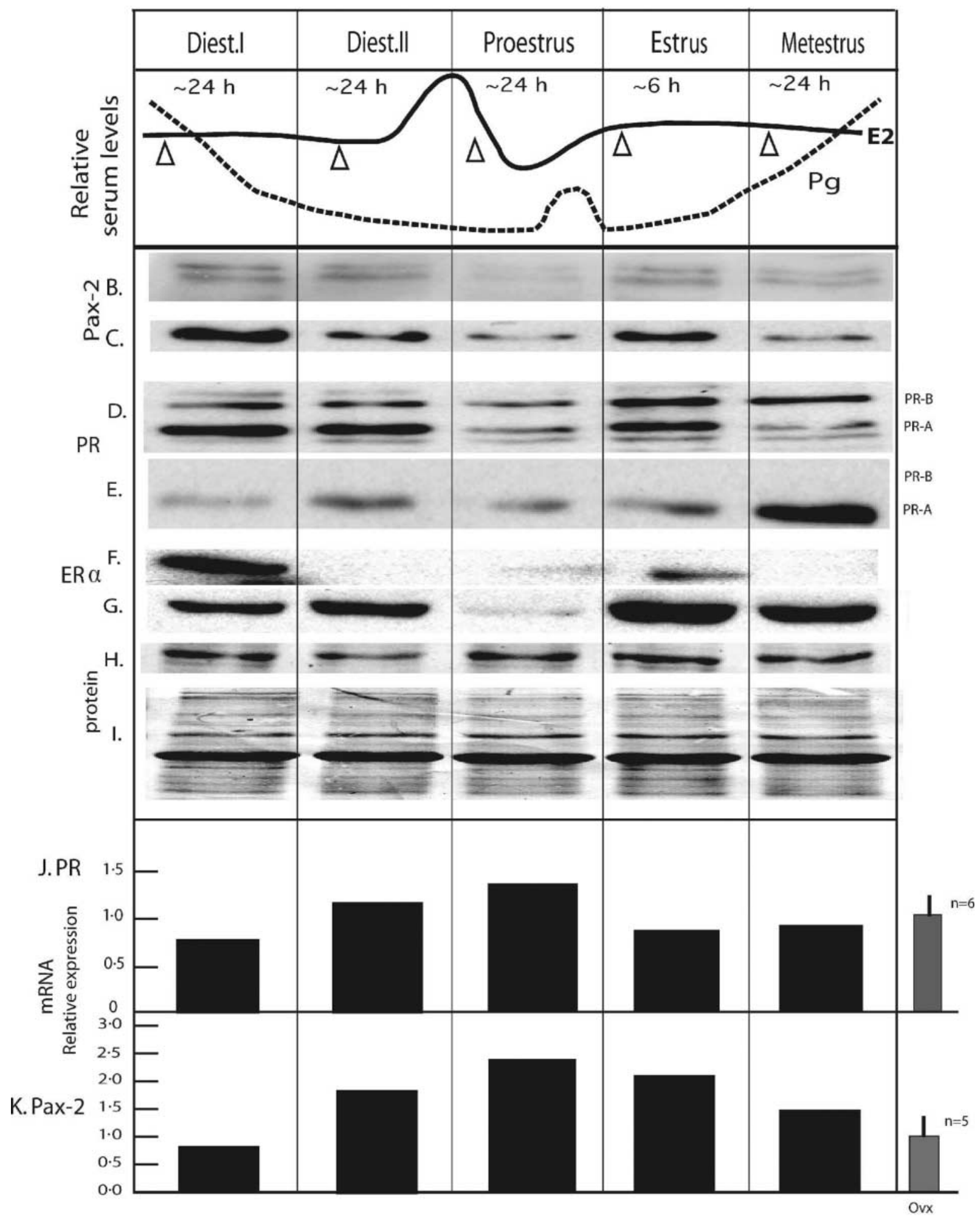


while restraining apoptosis (Maulbecker \& Gruss 1993 Stuart \& Gruss 1996). In the mammary gland, Pax-2 is expressed in a sub-population of stem cells thought to participate in regenerating mammary parenchyma for each new estrous cycle and pregnancy (Silberstein 2001, Silberstein et al. 2002). The availability of Pax-2 knockout mammary tissue allowed testing of the in vivo role of the transcription factor in mammary development and it was found that loss of function inhibited estrogen- and progesterone-stimulated development of the small ductal branches characteristic of early pregnancy. This phenotype was previously described in Wnt-4 knockout mammary glands, where progesterone-stimulated branching was blocked (Brisken et al. 2000). The similarities in the two mutant phenotypes led us to hypothesize that Pax-2 influences Wnt-4 expression (Silberstein et al. 2002).

The acute estrogen pulse in proestrus stimulates the secretion of pituitary luteinizing hormone/follicle-stimulating hormone (LH/FSH) leading to ovulation, but has no known role in the preparation of the mammary gland for pregnancy. In characterizing natural estrogen and progesterone regulation of $\mathrm{Pax}-2$ during the estrous cycle and using the expression of $\mathrm{ER} \alpha$ and $\mathrm{PR}$ as controls for steroid action, we discovered that ER $\alpha$, PR, and Pax-2 proteins underwent turnover in proestrus that delayed their expression until estrus. We now report evidence that this turnover and resulting time-delays are due to estrogen-triggered proteasomal proteolysis. The characteristics of these time-delays are similar to those found in other molecular timing systems such as circadian clocks, indicating that delays in $\mathrm{ER} \alpha, \mathrm{PR}$, and $\mathrm{Pax}-2$ expression reflect an underlying estrous cycle-responsive timing system in the mammary gland. Evidence is presented that Pax-2 is a molecular component of this timing system that schedules Wnt-4 expression. We discuss a function for the delays and timing system as adaptations to ensure optimal mammary development in anticipation of pregnancy.

\section{Materials and Methods}

\author{
Animals and hormone or proteasome inhibitor (PS-341) \\ treatments
}

All animal protocols were approved by the local Animal Research Committee and are in accord with National Institutes of Health (NIH) guidelines. Hormonally intact, virgin Balb/C female mice 12-24 weeks of age (ca $25 \mathrm{~g}$ ) were used for estrous cycle staging. For time-course and doseresponse studies, mice were ovariectomized at 2 months and treated with estrogen or progesterone after waiting at least 3 weeks for depletion of endogenous steroids. Hormone injections were administered s.c. with either estrogen $(5 \mu \mathrm{g}$ Depo-estradiol, Pharmacia/Upjohn, Kalamazoo, MI, USA) or progesterone (3 mg Depo-provera; Pharmacia/Upjohn). Similar doses, administered simultaneously, induce pregnancylike mammary development in endocrine-ablated mice (Nandi, 1959). The proteasome inhibitor PS-341 (gift of Millennium Pharmaceuticals, Inc., Cambridge, MA, USA) was administered i.v. via a tail vein at $0.5 \mathrm{mg} / \mathrm{kg}$ in normal saline (LeBlanc et al. 2002). Sporadic toxicity was seen at this dosage and affected animals were discarded.

\section{Estrous cycle staging}

Starting at 3 months of age, mice were estrus staged regularly in mid-morning through examinations of vaginal smears (Champlin et al. 1973). After assigning stages, animals were anaesthetized at mid-day and mammary glands removed. Since estrus occurs at night, animals for this stage were examined in late afternoon and the mammary glands removed in early evening.

\section{Pax-2-homozygous recessive (null) mammary tissue}

The Pax-2 null condition is embryonic lethal. To study mutant mammary tissue, 17-day $\mathrm{Pax}-2$ null $\mathrm{C} 3 \mathrm{H}$ embryos

Figure 1 Estrous cycle stage-dependent expression of Pax-2, PR, and ER $\alpha$ protein and Pax-2 and PR mRNA. (A) Murine estrous cycle stages: the approximate duration of each stage of an average 4-day cycle and relative levels of serum estrogen (solid line, E2) and progesterone (broken line, $\mathrm{Pg}$ ) are shown. Triangles indicate approximate killing point within each stage. Western immunoblot studies. The pictured murine estrous cycle chart reflects numerous endocrine studies that indicate an average length of cycle of $4-5$ days. A surge in serum estrogen beginning in late diestrus II and extending into early proestrus is reported for several strains of mice (Nelson et al. 1981, Walmer et al. 1992, Cohen et al. 1997, Jablonka-Shariff et al. 1999). The chart reflects this consensus, which is supported by the PR mRNA peak in proestrus that is indicative of estrogen action. A minor progesterone peak often seen in late proestrus (Bronson \& Desjardins 1974, Michael 1976, Ryan \& Schwartz 1980) or in early estrus (Walmer et al. 1992) is also shown. The approximate duration of each stage was assigned after staging 13 mice over 24 complete cycles. The average time from diestrus I to estrus was 3.46 days (S.D. 1.56 days). Considerable interanimal variation in estrous cycle regularity is common (Nelson et al. 1981 , 1982). Diest, diestrus. (B) Pax-2, nuclear protein: Pax-2a isoform (higher band) and Pax-2b isoform (lower band) are alternative splice variants (Dressler \& Douglass 1992). (C) Pax-2, cytoplasmic protein: only Pax-2a isoform detected. (D) PR, nuclear protein: major PR isoforms stained heavily. PR-A, lower band, PR-B, upper band. (E) PR, cytoplasmic protein: no PR-B was detected in the cytoplasmic fraction. (F) ER $\alpha$, nuclear protein. (G) ER $\alpha$, cytoplasmic protein. (H) Gel loading, nuclear protein. SDS-PAG Ponceau-stained for total protein. (I) Gel loading, cytoplasmic protein. (J) PR mRNA. Semi-quantitative RT-PCR was used to quantify steady-state transcript levels. Signals from ethidium bromide stained agarose gels were digitally captured and quantified using NIH Image (version 1.63). (K) Pax-2 mRNA. Real-time PCR was used to quantify steady-state transcript levels. Relative expression levels for Pax-2 and PR were calculated by normalizing values from staged animals to mammary glands from estrous cycle null (ovariectomized) mice (error bar $= \pm 1$ S.D.). Two sets of staged mice (2-3 mice per set) were studied and representative results are shown for each gene. PR values were also normalized against GAPDH expression for loading (GAPDH data not shown). 
were removed from the uterus and the mammary anlage excised. The rescue and clonal expansion of Pax-2 null mammary tissue has been described in detail elsewhere (Silberstein et al. 2002). To control for physiological and hormonal variation, gene expression in mutant and wild-type mammary parenchyma were compared in the same animal. To accomplish this, a fragment of mutant mammary parenchyma was transplanted into an inguinal mammary fat pad on one side of a Balb/C $n u / n u$ mouse creating a chimeric mammary gland comprised of $\mathrm{C} 3 \mathrm{H} \mathrm{Pax}-2$ null parenchyma in wild-type stroma. The contralateral gland served as a control and was transplanted with wild-type $\mathrm{C} 3 \mathrm{H}$ mammary tissue. Host mammary parenchyma was removed (cleared) prior to transplantation (Young 2000). Transplants were allowed to grow for at least 6 weeks to establish a ductal network after which animals were ovariectomized and treated with estrogen or progesterone as described above.

\section{Protein extraction and Western immunoblotting}

Protein extraction and Western immunoblotting (WIB) were carried out using standard procedures. Mammary glands were flash frozen and powdered under liquid nitrogen. A minimum of two nuclear and cytoplasmic lysate fractions were prepared from $60 \mu \mathrm{g}$ tissue powder using NE-PER Nuclear and Cytoplasmic Extraction Reagents (Pierce, Rockford, IL, USA) following the kit protocol. Protein concentration was determined using the bicinchaninic acid (BCA) Protein Assay Reagent Kit (Pierce). Electrophoresis, transfer and immuno-probing were done using standard procedures. Antibodies to Pax-2 (Covance, Berkeley, CA, USA), PR, and ER $\alpha$ (sc-538, sc-542; Santa Cruz Biotechnology, Santa Cruz, CA, USA) were used. The specificity of antibodies against $\mathrm{ER} \alpha$ and PR was demonstrated with cognate blocking peptides that eliminated all signals (not shown). The specificity of the Pax-2 antibody was inferred by WIB of lysates from 293 cells over-expressing Pax-2b (not shown) (Cai et al. 2002).

\section{Proteasome chymotrypsin assay}

Mouse mammary gland lysates were prepared for fluorometric assay of $20 \mathrm{~S}$ proteasome chymotryptic activity. The assay is based on the rate of cleavage of a four-peptide chymotryptic subunit attached to a fluorescent methyl coumarin reporter (LLVY-AMC, Chemicon, Temecula, CA, USA). Assay buffer and conditions were used according to the Chemicon Proteasome Activity Assay Kit. All the reactions were performed in triplicate at different lysate volumes and proportionality checked to ensure that rates were in the linear range of the assay. Protein concentration was determined by the BCA method and used to calculate specific activity. The specificity of the assay was tested by adding proteasome inhibitors such as lactacystin or PS-341, which resulted in between 85 and $90 \%$ inhibition. Statistical differences were analyzed with
Student's $t$-test. The proteasome inhibitory effect of injected PS-341 was tested and validated by assaying proteasomespecific chymotrypsin activity, which inhibited mammary gland $20 \mathrm{~S}$ proteasome enzyme activity by approximately $85 \%$ for up to $8 \mathrm{~h}$.

\section{Reverse transcriptase (RT)-PCR}

Mouse mammary gland RNA (3 $\mu \mathrm{g})$ isolated as previously described (Silberstein et al. 2002) was reverse transcribed using the Bio-Rad iScript cDNA Synthesis Kit under standard conditions. Reaction products were purified by the QIAquick PCR Purification Kit (Qiagen), and dried under vacuum to a volume of $25 \mu \mathrm{l}$. Reverse transcription reactions were evaluated by expression of the 'housekeeping' gene glyceraldehyde-3-phosphate dehydrogenase (GAPDH).

Semi-quantitative PCR was used to investigate expression of ER $\alpha$, PR, Wnt-4, Wnt-6, RANKL, and GAPDH using a Perkin-Elmer Gene Amp PCR System 2400 thermal cycler. Reaction products were analyzed by electrophoresis in $2 \%$ agarose gels. Pax- 2 and ER $\alpha$ primers were designed using MacVector software (MacVector 6.5, Oxford Molecular Group, San Francisco, CA, USA); other primers were taken from the literature as noted in the online Supplement. PCR primer sequences and amplification conditions are shown in Table 1. GADPH is a 'housekeeping gene' whose expression remains relatively constant during mammary development (Atwood et al. 1995).

Quantitative (real time) PCR Plasmids containing a human Pax-2 insert were obtained from ATCC Molecular Genomics Resources for use as a Pax-2 standard or control sequence (American Type Tissue Culture Collection, Manassas, VA, USA, catalog no. 9520324). Isolation of plasmids from $1.5 \mathrm{ml}$ liquid cultures of amp-resistant DH10B cells was performed using the QIPrep Spin Miniprep Kit (250) from Qiagen. Clones were verified by restriction digestion as well as by standard PCR. A standard dilution series of the plasmid preparations was made in the range of $10^{2}-10^{10}$ copies/ $\mu$ l. DNA concentrations were measured using the Nanodrop ND-1000 spectrophotometer (Nanodrop Technologies, Wilmington, DE, USA). Each $20 \mu 1$ realtime PCR was performed in triplicate. Reaction mixes contained $4 \mu \mathrm{l}$ plasmid or RT product, $1 \mu \mathrm{M} \mathrm{Pax}-2$ F5/B5 primers (see online Primer Table), and Bio-Rad iQ SYBER Green Supermix $2 \times \operatorname{mix}$ (Bio-Rad). Reactions were performed in a Bio-Rad real-time PCR detection system (iQ model iCycler, Bio-Rad). The reaction protocol consisted of the following cycles: $95^{\circ} \mathrm{C}$ for $5 \mathrm{~min}, 40$ cycles of $94^{\circ} \mathrm{C}$ for $1 \mathrm{~min}, 58^{\circ} \mathrm{C}$ for $2 \mathrm{~min}$, and $72{ }^{\circ} \mathrm{C}$ for $3 \mathrm{~min}$, followed by $72^{\circ} \mathrm{C}$ for $5 \mathrm{~min}, 95^{\circ} \mathrm{C}$ for $1 \mathrm{~min}$, twice, and 140 cycles of $95^{\circ} \mathrm{C}$ for $10 \mathrm{~s}$, decreasing $0.5^{\circ} \mathrm{C}$ after the second cycle for melt curve data collection. 
Table 1 PCR primer sequences

Primer set

$\mathrm{ER} \alpha$

$\mathrm{PR}$

Pax-2

Wnt-4

Wnt-6

RANKL

GAPDH
5'-CGAGGAGGGAGAATGTTGAAG-3'5'-CTGTCCAGGAGCAAGTTAGGAGC-3'

5'-CCCACAGGAGTTTGTCAAACTC-3' $5^{\prime}$-GTCATCACTTTTTGTGAAAGAG-

GAGCGGC-3'

5'-TCCGGACCAAAGTTCAGCAGCCT-3' $5^{\prime}$-AGTAGGATCCCACTGGGTCRTTR-3'

5'-AGGAGTGCCAATACCAGTTCC-3' $5^{\prime}$-TGTGAGAAGGCTACGCCATA-3 ${ }^{\prime}$

5'-CTTGGTCATGGATCCTACCA-3' $5^{\prime}$-GCAAACACGAAAGCTGTCTC-3'

5'-TGTACTTTCGAGCGCAGATG-3' ${ }^{\prime} 5^{\prime}$-CCCACAATGTGTTGCAGTTC-3'

5'-TTAGCACCCCTGGCCAAGG-3'5' -CTTACTCCTTGGAGGCCATG-3'
460

395

143

276

234

810

540

PCR amplification conditions: ER $\alpha$ : $94{ }^{\circ} \mathrm{C}$ for 5 min, 35 cycles of $95{ }^{\circ} \mathrm{C}$ for $30 \mathrm{~s}, 58{ }^{\circ} \mathrm{C}$ for $45 \mathrm{~s}$, and $72{ }^{\circ} \mathrm{C}$ for $30 \mathrm{~s}$, followed by an extension step of $72{ }^{\circ} \mathrm{C}$ for $7 \mathrm{~min}$. PR: $94^{\circ} \mathrm{C}$ for $1 \mathrm{~min}, 55^{\circ} \mathrm{C}$ for $2 \mathrm{~min}, 72^{\circ} \mathrm{C}$ for 2 min for $29 \mathrm{cycles}$, then $72{ }^{\circ} \mathrm{C}$ for $5 \mathrm{~min}$. Primers: (Hovey et al. 2001). Wnt- 4 and Wnt- 6 , a standard touchdown protocol was used (Don et al. 1991). Primers: Cathrin Brisken (personal communication). RANKL: $94{ }^{\circ} \mathrm{C}$ for $35 \mathrm{~s}, 65^{\circ} \mathrm{C}$ for $35 \mathrm{~s} 72{ }^{\circ} \mathrm{C}$ for $1 \mathrm{~min}$ for 10 cycles, then $94{ }^{\circ} \mathrm{C}$ for $35 \mathrm{~s}, 60^{\circ} \mathrm{C}$ for $35 \mathrm{~s}, 72{ }^{\circ} \mathrm{C}$ for 1 min for 5 cycles, $94^{\circ} \mathrm{C}$ for $35 \mathrm{~s}, 55^{\circ} \mathrm{C}$ for $35 \mathrm{~s}, 72{ }^{\circ} \mathrm{C}$ for 1 min for $5 \mathrm{cycles}, 94{ }^{\circ} \mathrm{C}$ for $35 \mathrm{~s}, 50{ }^{\circ} \mathrm{C}$ for $35 \mathrm{~s}$, $72{ }^{\circ} \mathrm{C}$ for $1 \mathrm{~min}$ for $5 \mathrm{cycles}, 94^{\circ} \mathrm{C}$ for $35 \mathrm{~s}, 50^{\circ} \mathrm{C}$ for $35 \mathrm{~s}, 72{ }^{\circ} \mathrm{C}$ for 1 min for 5 cycles, $94{ }^{\circ} \mathrm{C}$ for $35 \mathrm{~s}, 45^{\circ} \mathrm{C}$ for $35 \mathrm{~s}, 72{ }^{\circ} \mathrm{C}$ for 1 min for 5 cycles, followed by $72{ }^{\circ} \mathrm{C}$ for 7 min. Primers: (Brisken et al. 2002). GAPDH: $94{ }^{\circ} \mathrm{C}$ for 2 min, 25 cycles of $94{ }^{\circ} \mathrm{C}$ for $30 \mathrm{~s}, 55^{\circ} \mathrm{C}$ for $30 \mathrm{~s}$, and $72{ }^{\circ} \mathrm{C}$ for $30 \mathrm{~s}$, followed by an extension step of $72{ }^{\circ} \mathrm{C}$ for $7 \mathrm{~min}$. Primers: Invitrogen.

Pax-2 sequence analysis for estrogen and progesterone responsive regulatory motifs the Mus musculus

Pax-2 gene (NM_0011037) was analyzed for estrogen and progesterone regulatory motifs using genomic sequence from the University of California, Santa Cruz mouse genome browser chromosome 19: 44092045-44174678, which includes $4 \mathrm{~kb}$ of flanking sequence (http://genome.ucsc. edu). Estrogen response element (ERE) consensus: AGGTCANNNTGACCT (Schuchard et al. 1993). ERE half site: TGACC or GGTCA (Sathya et al. 1997, Petz \& Nardulli, 2000). Progesterone response element (PRE) consensus: AG (A/G) ACANNNTGTACC. PRE half site: AGAACA, AGGACA, or TGTACC (Nelson et al. 1999). SP-1 (GC box) site: CCGCC, GCCCCCTCCCC, GCCCGCCCA, CCCCTCC, AGGCGG, GGGCGGAGC, or AGGGCGGGGC (Xiong et al. 2000, Hilton \& Wang, 2003). Activator protein 1 response element (AP-1) site: TGA (G/C) TCA (Lee et al. 1987). Complementary sequences for each motif were included in the analysis.

\section{Results}

Turnover of Pax-2, PR, and ER $\alpha$ protein during the estrous cycle

To investigate the dynamics of $\mathrm{Pax}-2$ protein during the estrous cycle, mature female mice that had undergone at least two complete estrous cycles were staged by vaginal histology. After killing early in each stage of the cycle, their mammary glands were surgically excised, extracts of nuclear and cytoplasmic protein prepared, and the expression of Pax-2, PR, and ER $\alpha$ protein investigated by WIB. Pax-2 protein levels were elevated in diestrus I and II, decreased dramatically in proestrus, and then were restored during estrus (Fig. 1B,C). The simultaneous depletion of both nuclear and cytoplasmic isoforms indicated a net loss of protein, rather than a transfer of $\mathrm{Pax}-2$ between these compartments, while the absence of generalized protein depletion indicated that the loss of Pax-2 protein was specific (Fig. 1H,I). Estrous cycle expression of $\mathrm{ER} \alpha$ and $\mathrm{PR}$ isoforms was investigated to determine whether protein loss extended to other regulatory proteins essential to mammary gland secretory development. PR and ER $\alpha$ proteins were also depleted in proestrus and restored in estrus mirroring the flux of Pax-2 (Fig. 1D-G). With the possible exception of PR-A in metestrus, there was no evidence that transfer between the nuclear and cytoplasmic compartments accounted for Pax-2, PR, and ER $\alpha$ dynamics during the estrous cycle.

The fact that the turnover of Pax-2, PR, and ER $\alpha$ was initiated around proestrus suggested a possible connection to the estrogen surge in that stage. To investigate whether our staging of proestrus coincided with the surge, we predicted that PR transcription, which is driven by estrogen, should be elevated in proestrus. PR mRNA levels were analyzed by semi-quantitative RT-PCR and peak PR transcription was detected in proestrus confirming that our proestrus staging followed the estrogen surge (Fig. 1J). Real-time PCR was used to detect low-copy number Pax-2 transcripts and, as with PR, the highest levels were also detected during proestrus suggesting that the $\mathrm{Pax}-2$ gene is sensitive to changing estrogen concentrations (Fig. 1K).

\section{Estrogen stimulates turnover of Pax-2, PR, and ER $\alpha$}

As noted, the main endocrine feature in late diestrus II/early proestrus is the strong estrogen pulse. Therefore, it was of interest to investigate whether estrogen could account for the observed turnover of $\mathrm{Pax}-2, \mathrm{PR}$, and ER $\alpha$ proteins. To address this question requires testing the effects of an estrogen pulse in isolation, removed from endogenous ovarian steroids and the estrous cycle. Surgical removal of the ovaries (ovariectomy) leaves an 'estrous cycle null' animal that is the standard experimental model for studying the effects of ovarian hormones. In ovariectomized mice, depending on the individual transcription factor and whether it was in the 
nucleus or cytoplasm, a single estrogen injection replicated all or some elements of natural loss and restoration seen during the estrous cycle. Focusing first on protein loss, estrogen caused a dramatic downregulation of nuclear Pax-2, PR, and ER $\alpha$ starting $1-2 \mathrm{~h}$ after treatment (Fig. 2A,C,E). Interestingly, Pax-2 protein, which was nearly absent in the mammary glands of untreated animals (time zero), was moderately induced $1 \mathrm{~h}$ after treatment and then depleted. This contrasted with nuclear PR and ER $\alpha$ proteins, which were relatively abundant in the absence of estrogen and underwent depletion only after hormone treatment. The loss of Pax-2 and PR in the cytoplasm was also dramatic, but occurred over a longer period; cytoplasmic Pax-2 reached a nadir at $12 \mathrm{~h}$ compared with $4 \mathrm{~h}$ in the nucleus. For PR cytoplasmic and nuclear PR both reached a nadir at $2 \mathrm{~h}$, but lower cytoplasmic levels persisted to $4 \mathrm{~h}$ with some recovery apparent by $8 \mathrm{~h}$. Unlike the Pax- 2 and PR, cytoplasmic ER $\alpha$ levels steadily declined beginning at $4 \mathrm{~h}$ until the end of the study at $24 \mathrm{~h}$. Taken together, the absence of generalized protein loss, relatively even protein loading (Fig. 2G) and the observation that transfers between the nuclear and cytoplasmic compartments appear unlikely to account for the observed changes, supports a conclusion that Pax-2, PR, and $\mathrm{ER} \alpha$ proteins were specifically targeted for depletion.

During the estrous cycle, replenishment of Pax-2, PR, and $\mathrm{ER} \alpha$ protein apparently begins sometime in proestrus and

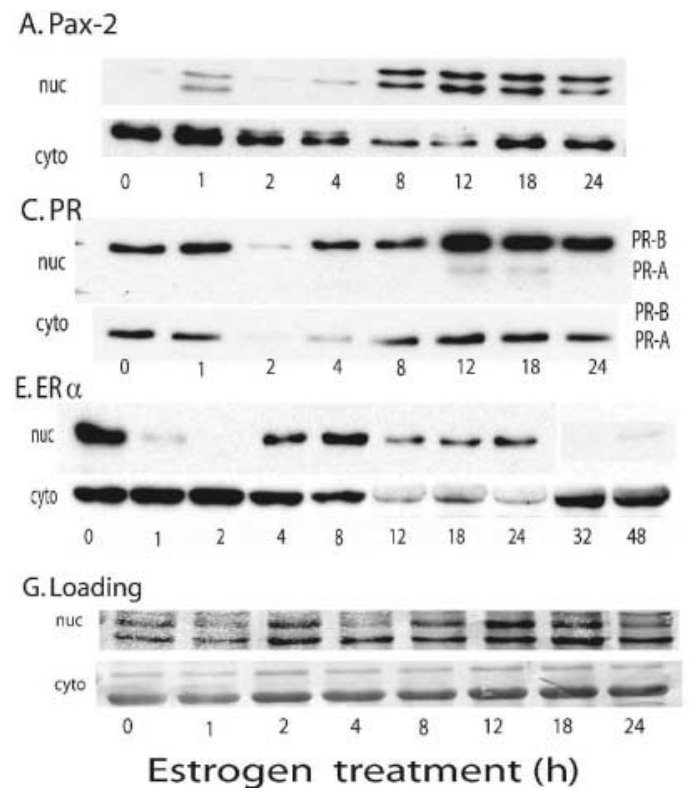

extends into estrus (Fig. 1B-G). Since this probably takes place as estrogen levels rebound from their trough in early proestrus, it raised the question of whether the restoration of each protein depended on a second 'dose' of estrogen or whether a single estrogen pulse can stimulate restoration as well as loss. The results of the estrogen repletion/time-course study show that, in addition to degradation, a single dose of estrogen also stimulated restoration of $\mathrm{Pax}-2, \mathrm{PR}$, and ER $\alpha$ protein (Fig. 2A,C,E). As with degradation, the timing of restoration within the nuclear and cytoplasmic compartments differed for each protein. Nuclear Pax-2 levels increased at $8 \mathrm{~h}$, cytoplasmic levels after $12 \mathrm{~h}$. Levels of PR increased by $12 \mathrm{~h}$ in each compartment, while ER $\alpha$ transiently increased from 4 to $8 \mathrm{~h}$ only in the nucleus. The time-course of Pax-2 and $\mathrm{PR}$ protein expression was also studied in the uterus and found to undergo decay and replenishment after estrogen treatment, but with timing different from that seen with the mammary gland (data not shown).

\section{Estrogen-stimulated proteasome activity and Pax-2, PR, and $E R \alpha$ protein turnover}

Ligand-activated degradation of $\mathrm{ER} \alpha, \mathrm{PR}$, and other steroid receptor proteins by the ubiquitin-proteasome system (UPS) is well known and degradation times for mammary $\operatorname{ER} \alpha$ and PR (Fig. 2: $18+\mathrm{h}$ vs $2-4 \mathrm{~h}$ ) approximated the times
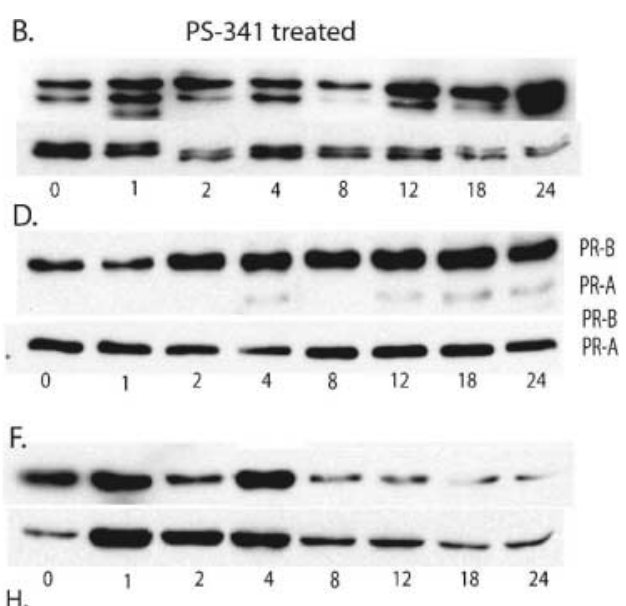

H.

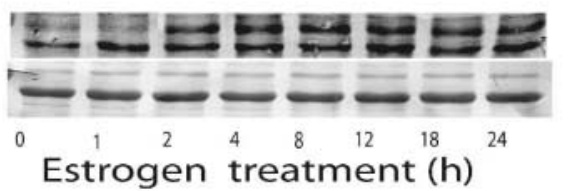

Figure 2 Time-course of estrogen-dependent Pax-2, PR, and ER $\alpha$ proteolysis and effects of the proteasome inhibitor, PS-341. Ovariectomized mice received a single injection of estrogen and three animals were killed at each time point. Two separate time-course experiments were performed and cytoplasmic and nuclear protein fractions analyzed by WIB with representative results shown. (A, C, E, G) Estrogen treatment only. (B, D, F, H) Animals treated with PS-341 for $1 \mathrm{~h}$ prior to estrogen injection. The effect of PS-341 treatment on proteasome activity was independently tested by assaying proteasome chymotryptic activity in mammary tissue samples; in treated animals proteolysis was inhibited by approximately $60 \%$ from time 0 to $8 \mathrm{~h}$ with inhibition declining to $36 \%$ at $12 \mathrm{~h}$ and $18 \%$ at $18 \mathrm{~h}$ (data not shown). (A, B) Pax-2; (C, D) PR. No PR-B was detected in cytoplasmic fractions; $(E, F) E R \alpha ;(G, H)$ loading control. SDS-PAG, Ponceau-stained for total protein. 
observed for UPS-dependent ER $\alpha$ and PR degradation in cell lines (Alarid et al. 1999, El Khissiin \& Leclercq 1999, Lange et al. 2000, Nawaz \& O'Malley 2004, Tsai et al. 2004). To investigate possible proteasome modulation of estrogenstimulated turnover of mammary gland Pax $-2, \mathrm{PR}$, and ER $\alpha$, ovariectomized mice were treated with a specific inhibitor of 20 S proteasome chymotryptic activity, PS-341, via tail-vein injection $1 \mathrm{~h}$ prior to an estrogen injection and animals sacrificed up to $24 \mathrm{~h}$ after estrogen treatment.

PS-341 strongly inhibited the turnover of nuclear Pax-2, PR, and ER $\alpha$ protein and further differentiated Pax-2 dynamics from that of PR or ER $\alpha$ (Fig. 2B,D,F). For Pax-2, but not the other proteins, after PS-341 treatment and prior to estrogen injection, a proteasome blockade caused significant build-up of Pax-2 (compare Fig. 2A and B, time $=0 \mathrm{~h}$ ), demonstrating that proteasome-dependent Pax2 turnover was highly active in the mammary glands of endocrine-ablated animals and, therefore, did not require estrogen activation. After estrogen treatment, PS-341 caused nuclear Pax-2 protein levels to rise and remain elevated for the 24-h duration of the experiment except for a dramatic decline at $8 \mathrm{~h}$, (Fig. 2B). This decline coincided with a buildup of nuclear Pax-2 in the untreated animals (Fig. 2A), indicating that it could be due to decreased turnover. Pax-2 mRNA levels were at baseline at $8 \mathrm{~h}$, demonstrating that this is in fact the case (Fig. 3A). Elevation of Pax-2 nuclear protein levels by decreased proteolysis at $8 \mathrm{~h}$, contrasted dramatically with elevated Pax-2 protein at $12 \mathrm{~h}$, which coincided with the transcriptional peak (Fig. 3A). At $12 \mathrm{~h}$ (and also at $1 \mathrm{~h}$ ), new transcription apparently overcomes Pax-2 proteolysis. Nuclear ER $\alpha$ degradation was strongly inhibited by PS-341 from 1 to $4 \mathrm{~h}$ after estrogen treatment, while inhibition of nuclear PR turnover was delayed until $2 \mathrm{~h}$ and then extended for the duration of the study. The timing of PS-341 effects on the turnover of cytoplasmic Pax -2 and PR differed markedly from nuclear turnover and reflected the generally later cytoplasmic turnover of the proteins (Fig. 2B,D). For ER $\alpha$, effects on cytoplasmic turnover coincided for the most part with effects on nuclear turnover (Fig. 2F).

\section{Estrogen-regulated Pax-2, PR, and ER $\alpha$ transcription}

The targeted degradation of $\mathrm{Pax}-2, \mathrm{PR}$, and ER $\alpha$ proteins and inhibition by PS-341 are strong evidence for proteasome action. A third signature of proteasome action is when protein loss occurs against a background of relatively stable levels of cognate transcript. To investigate $\mathrm{Pax}-2, \mathrm{PR}$, and ER $\alpha$ protein dynamics with respect to transcription, total RNA was extracted from mammary glands from ovariectomized

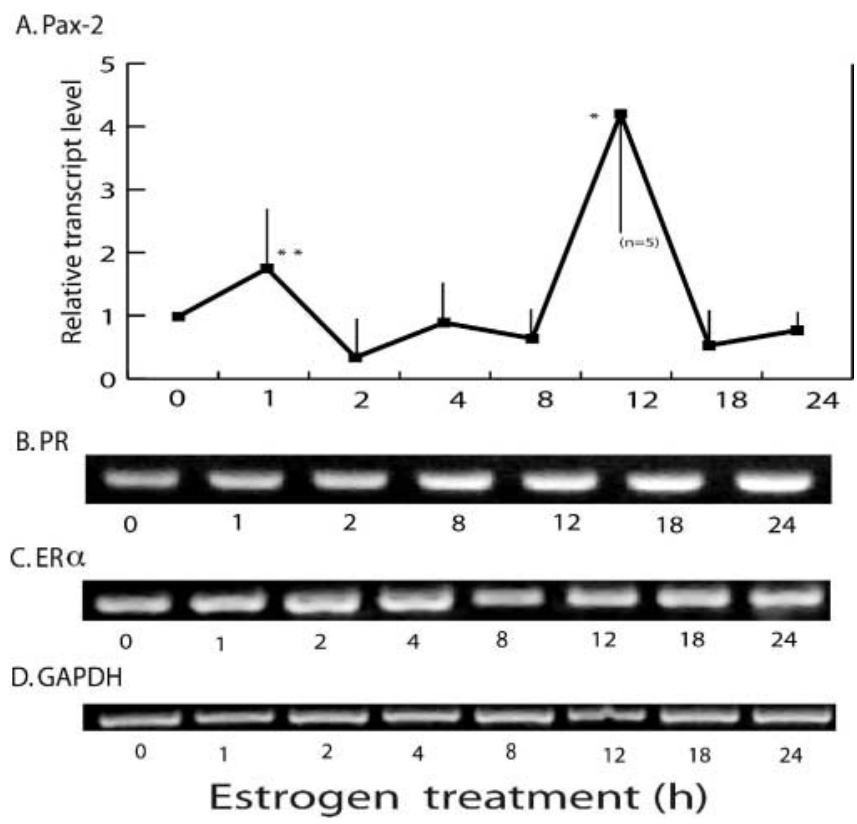

Figure 3 Time-course of estrogen-dependent changes in Pax-2, PR, and ER $\alpha$ mRNA. (A) Pax-2 mRNA. Real-time PCR. Relative expression was calculated by normalizing the data points to a 'no treatment' value (time, 0 h) of1.0. Error bars represent S.D. *indicates that the 12-h time point was significantly different from all other time points except the 1-h time $P<0.05$ Student's $t$-test; ${ }^{* *}, 1$-h time point was significantly different from $12 \mathrm{~h}$ at $P<0 \cdot 1$. Three animals were used per time point, except for five at 12 h. (B) Progesterone receptor, standard RT-PCR. (C) Estrogen receptor. (D) GAPDH, mRNA loading. Levels of GAPDH were stable during the treatment period indicating that the estrogen effects were gene-specific. 
mice at various times after estrogen treatment and analyzed by RT-PCR (real-time analysis for Pax-2).

Levels of Pax-2, PR, and ER $\alpha$ transcript did not remain stable after estrogen treatment. Pax-2 transcript concentration was elevated $1 \mathrm{~h}$ after estrogen treatment (Fig. 3A), echoed by increases in $\mathrm{Pax}-2$ protein in both compartments at that time point (Fig. 2A). Transcript and protein levels then declined between 2 and $8 \mathrm{~h}$ indicating that lower protein levels reflected transcriptional as well as proteasomal regulation. By contrast, the sharp increase in $\mathrm{Pax}-2$ nuclear protein at $8 \mathrm{~h}$ did not reflect enhanced transcription, but rather coincided with decreased proteasome action (see Fig. 2B, $8 \mathrm{~h}$ ). This was a striking counterpoint to an approximately fourfold increase in Pax-2 transcripts and elevated Pax-2 protein at $12 \mathrm{~h}$ that followed the nadir in Pax-2 cytoplasmic protein (Fig. 2B, $12 \mathrm{~h}$ ). Unlike Pax-2, PR transcript levels were stable up to $2 \mathrm{~h}$, while cognate protein was lost in both compartments at the latter time suggesting pure proteasome action (Fig. 3B). Increased transcript levels at $8 \mathrm{~h}$ followed a nadir in PR protein between 4 and $8 \mathrm{~h}$. For ER $\alpha$, declining transcript levels after $4 \mathrm{~h}$ mirrored similar dynamics for cognate proteins also beginning at $8 \mathrm{~h}$. These results indicate that for Pax-2 and PR, observed protein levels reflect a complex balance between proteolysis and transcription. Also, for each gene, the greatest increase in transcription was delayed several hours after the estrogen pulse and followed a nadir in cognate protein in the cytoplasm.

\section{Proteasome chymotrypsin activity during the estrous cycle}

Collectively, our findings are consistent with proteasome mediation of estrogen-stimulated Pax-2, PR, and ER $\alpha$ protein loss and suggest that this mechanism could account for the delays in the expression of each protein that followed the estrogen surge in proestrus. To evaluate proteasome activity during the estrous cycle, the primary (chymotryptic) peptidase activity of the proteasome was assayed in mammary tissue taken from each stage in the estrous cycle (Fig. 4). Degradation of the proteasomespecific, fluorogenic chymotrypsin substrate, LLVY-AMC, was elevated by about $40 \%$ (significance: $*, \quad P<0.01$; **, $P<0.001$; Student's $t$-test) during proestrus compared with the other stages. A similar pattern and increase was seen with uterine tissue (not shown). Therefore, the highest proteasome chymotryptic activity correlated with loss of $\mathrm{Pax}-2, \mathrm{PR}$, and $\mathrm{ER} \alpha$ protein in proestrus, indicating that the UPS cascade was present and activated, and could thus participate in degradation of the three proteins.

Turnover of Pax-2 and PR is correlated with expression of genes critical to mammary secretory development

Pax-2, PR, and ER $\alpha$ are proteins that are essential for mammary secretory development. Therefore, we hypothesized that the delays caused by their turnover might influence functional

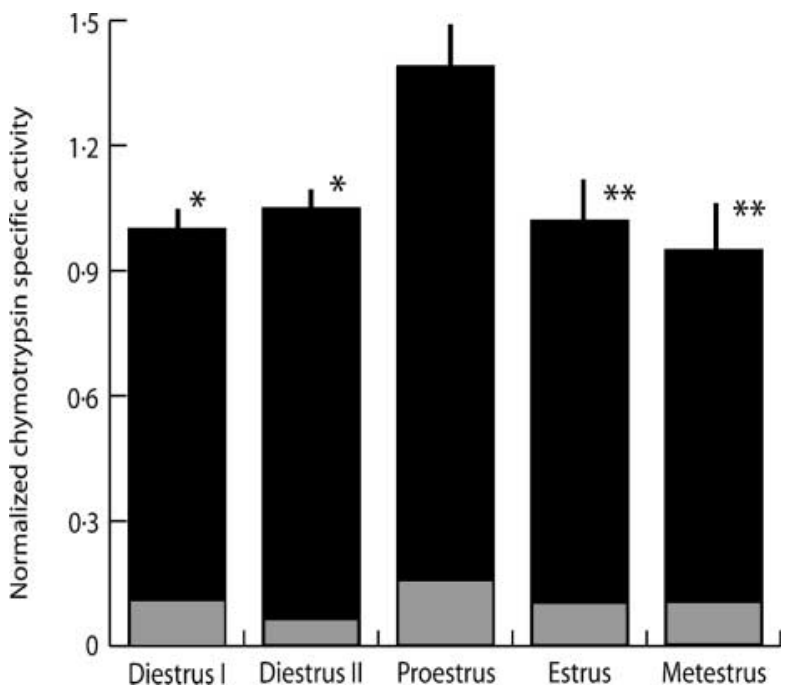

Figure 4 Proteasome chymotryptic activity at different stages of the estrous cycle. Enzyme activity was assayed using the LLVY-AMC fluorogenic substrate in multiple lysates prepared from two independent sets of estrus-staged animals and normalized to a value of 1.0 for diestrus I. Non-proteasome-specific chymotrypsin activity was determined by adding PS-341 to a reaction; proteasomespecific activity was then determined by subtracting nonspecific activity (gray insets) from total activity. Statistical significance for proteasome-specific activity (black) was significantly greater in proestrus compared with either diestrus stage $(*, P<0 \cdot 01)$ or in estrus and metestrus $(* *, P<0 \cdot 001)$.

development. To investigate this possibility, the estrous cycle patterns of expression of two molecular markers of secretory development, Wnt-4 and RANKL, were compared with that of their putative transcriptional regulators, $\mathrm{Pax}-2$ and $\mathrm{PR}$.

Estrous cycle expression of Wnt-4 and RANKL mRNA was analyzed by standard RT-PCR on total RNA extracted from staged mice. Wnt-4 transcript levels were depressed in proestrus and elevated in estrus, mirroring the pattern of $\mathrm{Pax}-2, \mathrm{PR}$, and ER $\alpha$ protein (compare Figs $5 \mathrm{~A}$ and 1). The related mammotropic growth factor, Wnt-6 is, by contrast, expressed in the mammary gland in late pregnancy and, as expected, its expression was not correlated with the dynamics of either Pax-2 or the steroid receptors (Fig. 5B) (Weber-Hall et al. 1994). The expression of RANKL was depressed in proestrus and then elevated in estrus closely following the restoration of PR protein and the coordinate rise in its cognate ligand (Fig. 5C). The renewed expression of Wnt-4 and RANKL in estrus was consistent with the expected commencement of secretory development in that stage and suggested a functional relationship between Pax-2, PR, or ER $\alpha$ turnover and the timing of estrous cycle secretory development.

\section{Pax-2 regulates the timing of estrogen-induced Wnt-4 expression}

The coincident loss and recovery of Pax -2 and Wnt-4 from diestrus II to estrus suggested that the timing of Pax-2 and Wnt-4 expression might be related through the estrogen pulse and Pax-2 proteolysis. To investigate this question, the 


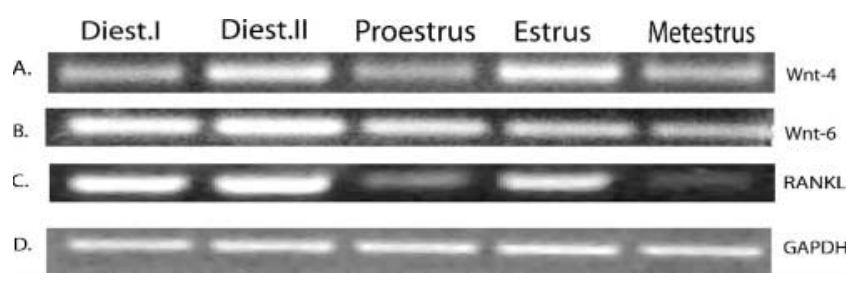

Figure 5 RT-PCR analysis of estrous cycle regulation of Wnt-4, Wnt-6, and RANKL mRNA expression. (A) Wnt-4; (B) Wnt-6; (C) RANKL; (D) GAPDH control. GAPDH transcript levels were relatively constant during the estrous cycle indicating that the observed differences in Wnt-gene and RANKL expression were not due to variations in input RNA concentration.

estrogen supplemented, ovariectomized mouse model was again employed, this time to follow the time-course of Wnt-4 mRNA expression with respect to $\mathrm{Pax}-2$ protein turnover. After estrogen treatment, there was an 18-h delay before steady-state Wnt-4 transcript levels dramatically increased (Fig. 6A). The same 18-h delay was observed in a second mouse strain indicating that it is a conserved property of estrogen-induced Wnt-4 expression in the mouse mammary gland (Fig. 6B). This delay coincided with the time taken for Pax-2 to be lost from the cytoplasm (Fig. 2A). In contrast to estrogen, the induction of Wnt-4 by progesterone occurred over a much shorter period, between 1 and $8 \mathrm{~h}$ posttreatment depending on mouse strain (Fig. 6D,E).

The coincident restoration of cytoplasmic Pax-2 protein and induction of Wnt-4 mRNA by estrogen at $18 \mathrm{~h}$ was consistent with a Pax-2/Wnt-4 regulatory relationship. To directly test, this hypothesis required investigating Wnt-4 expression in the absence of $\mathrm{Pax}-2$, in Pax-2-null mammary tissue. Therefore, we employed a transplant system in which Pax-2 knockout mammary tissue was surgically implanted into mammary fat pads that had been previously cleared of host epithelium. Earlier studies showed that these Pax-2 null transplants develop a normal ductal system, but fail to form minor branches (Silberstein et al. 2002). For controls, syngenetic wild-type mammary tissue was transplanted into the opposite (contralateral) gland, so the mutant and wildtype tissues grew within the same wild-type connective tissue in the same animal. Therefore, mutant and control tissues were subject to identical endocrine and physiological conditions.

When mice carrying mutant and wild-type mammary glands were ovariectomized and then treated with estrogen, the timing of Wnt-4 expression in the Pax-2 mutant tissue was dramatically affected. While Wnt-4 induction in the control tissue exhibited the 18-h delay, Wnt-4 mRNA expression in mutant tissue occurred much more rapidly, $1 \mathrm{~h}$ after injection, and peaked $10 \mathrm{~h}$ early, at $8 \mathrm{~h}$ (Fig. 6C). Importantly, the loss of Pax-2 only affected the timing of Wnt-4 expression and not steady-state transcript levels, which were equivalent in the knockout and wild-type tissues (Fig. 6B, C; compare signal strength at $18 \mathrm{~h}$ vs $8 \mathrm{~h}$ ). This effect was specific for Wnt-4 insofar as the expression of numerous other genes associated with mammary development later in pregnancy, including Wnt-6, the prolactin receptor, IGF-2, IGF-1 receptor, and RANKL were unaffected by the Pax-2 mutation (data not shown). In contrast to estrogen,

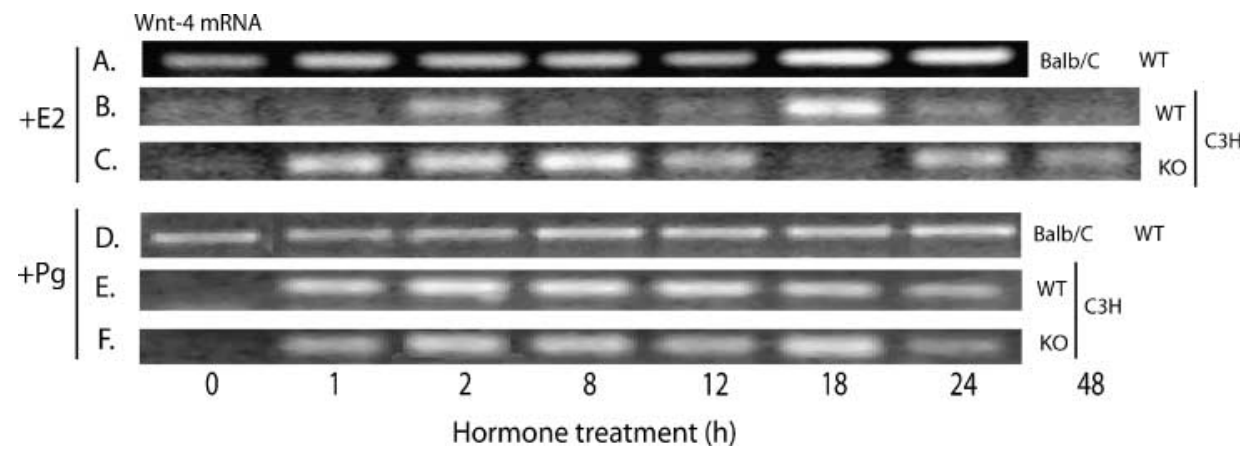

Figure 6 Effect of mammary gland Pax-2 knockout on the timing of estrogen- vs progesterone-induced Wnt-4 expression. Immuno-deficient female mice whose mammary fat pads had been surgically cleared of host parenchyma received contralateral transplants of Pax-2 null and wild-type (WT) mammary tissue. After allowing 8-12 weeks for mammary duct outgrowth, these mice received a single s.c. injection of estrogen $(5 \mu \mathrm{g})$ and two animals were killed at each time point. For the Pax-2 knockout (KO) experiment, three separate sets of animals were used. For the other experiments two sets of animals were treated. Representative results are shown. (A-C) Estrogen treatment. Mouse strain and genotype:

(A) Balb/C, wild-type; (B) $\mathrm{C} 3 \mathrm{H}$, wild-type; (C) $\mathrm{C} 3 \mathrm{H}$, Pax-2 knockout respectively. (D-F) Progesterone treatment. Mouse strain and genotype: as above. 
progesterone treatment had little or no effect on either the timing or level of Wnt-4 expression in Pax-2 knockout mammary glands (Fig. 6E, F). The studies of Wnt-4 expression in wild-type and Pax-2 null mammary tissues lead us to conclude that Pax-2 can specifically delay expression of estrogen-induced Wnt-4. Furthermore, the duration of the Wnt-4 delay is correlated with the time necessary to degrade pre-existing cytoplasmic, not nuclear Pax-2 (compare Fig. 2A, timing of $\mathrm{Pax}-2$ protein degradation with Fig. 6A, B, Wnt-4 expression). While Pax-2 clearly affects the timing of Wnt-4 expression, early Wnt-4 expression at $2 \mathrm{~h}$ in wild-type mice (Fig. 6A, B) indicates that Pax-2 may not be the sole determinant of timing.

\section{Pax-2 gene expression is estrogen-responsive}

$\mathrm{ER} \alpha$ and $\mathrm{PR}$ are the archetypal estrogen-responsive genes; by monitoring the changing concentrations of ovarian steroids, they regulate constellations of genes in a variety of cells and tissues during the estrous cycle. By contrast, transcription factors dedicated to timing the estrogen response of a single gene during the estrous cycle have not been described. If the Pax-2 gene encodes such a protein, then it should be responsive to estrogen concentration. The observation that peak Pax-2 mRNA levels during the estrous cycle occurred in proestrus suggests this is, in fact, the case (Fig. 1K). To directly test the sensitivity of the $\mathrm{Pax}-2$ gene to estrogen, ovariectomized mice were injected with different concentrations of the hormone and Pax-2 mRNA levels were analyzed by quantitative RT-PCR $8 \mathrm{~h}$ later. The PR gene is responsive to estrogen concentration and was included as a control. For Pax-2 the lowest doses of estrogen were stimulatory, with higher doses being slightly inhibitory (Fig. 7A). PR expression was also induced, but only by the higher doses of estrogen (Fig. 7B). The twofold increases in Pax-2 and PR expression were of roughly the same magnitude as those seen under natural conditions in the estrous cycle (Fig. 1).

The sensitivity of a gene to different estrogen concentrations is conferred by multiple, dispersed ERE (Kraus et al. 1994, Sathya et al. 1997). To investigate further the potential of Pax-2 to respond directly to estrogen, the murine Pax-2 gene was analyzed for these and related motifs. A large number of estrogen-responsive motifs (328), including perfect and half EREs, were found primarily within introns throughout the gene along with non-ERE, SP-1, and AP-1 motifs (96 and 22, respectively) that can interact with half EREs to activate gene expression in the presence of liganded ER $\alpha$. Pax-2 had half as many progesterone responsive elements as EREs (160) (Table 2).

The possibility that estrogen concentration-dependent expression of Pax-2 has functional consequences with respect to Wnt-4 was investigated by studying Wnt-4 mRNA expression relative to the expression of $\mathrm{Pax}-2$ protein and estrogen concentration. The concentrations of estrogen that stimulated the strongest induction of $\mathrm{Pax}-2$ transcript and protein (1 ng) also stimulated maximal induction of Wnt-4 transcripts (Fig. 7C). Levels of GAPDH varied somewhat, but could not account for the differences in Wnt-4 expression. PR mRNA expression was not correlated with either Wnt-4 or Pax-2 expression.

\section{Discussion}

During the estrous cycle, periodic surges of estrogen and progesterone stimulate rudimentary mammary gland secretory development. This begins during estrus and is timed to coincide with ovulation and possible fertilization thereby anticipating pregnancy. The dynamics of the proteins that are essential for secretory development, ER $\alpha, \mathrm{PR}$, and $\mathrm{Pax}-2$, have not previously been investigated in the context of the estrous cycle. Unexpectedly, these proteins were subjected to turnover in proestrus when relatively high levels in diestrus declined dramatically and were subsequently restored in estrus (Fig. 1). Loss of ER $\alpha$ in primate (Rhesus monkey) mammary glands in the late follicular phase of the estrous cycle (comparable to diestrus II/proestrus in mice) has been described and suggests that turnover of mammary $\operatorname{ER} \alpha$ in proestrus also occurs in higher mammals (Cheng et al. 2005).

The observation that ER $\alpha$ was depleted around the estrogen surge in late diestrus suggested that estrogen might trigger downregulation of its receptor in the mammary gland as it does in nonmammary ovarian target tissues (Horigome et al. 1988). Estrogen did in fact stimulate turnover of $\mathrm{ER} \alpha, \mathrm{PR}$, and Pax-2 protein when it was injected into an estrogen-depleted (ovariectomized) mouse (Fig. 2). While it is not possible to relate the time-course data directly to estrous cycle timing (no reproducible 'time zero' exists on which to base an estrous cycle time-course study), this study does demonstrate that estrogen, acting alone, can stimulate the depletion as well as renewal of each protein. An artificial estrogen surge therefore broadly mimicked its natural counterpart indicating that the estrogen pulse in proestrus is the most likely candidate to activate turnover of the three transcription factors during the estrous cycle.

The most striking observations in this study were, by far, the time-delays in Pax-2, PR, and ER $\alpha$ expression in proestrus and after an estrogen treatment in the ovariectomized mouse. In eukaryotic cells, time-delayed gene expression is central to the function of cyclic molecular systems such as the circadian and somite-segmentation clocks as well as mitosis (den Elzen \& Pines, 2001, Hirata et al. 2002, McGowan, 2003, Pourquie \& Goldbeter, 2003, Van Gelder et al. 2003). Reduced to essentials, these time-delays depend on regulated protein stability, typically by phosphorylation and ubiquitination, and all share molecular mechanisms that include: (1) proteasome-dependent proteolysis, (2) proteins dedicated to regulating timing, and (3) regulation of gene expression by negative feedback (Monk, 2003, Van Gelder et al. 2003, Eide et al. 2005). In addition, recent evidence from circadian clock studies have demonstrated that the molecular mechanisms governing time-delays lasting several hours or more (long-duration delays) reside in the cytoplasm, not the 


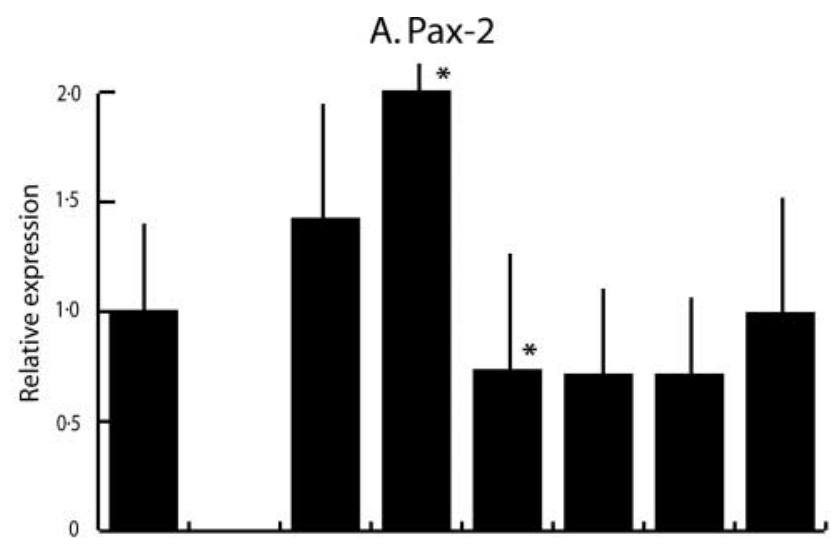

B. PR

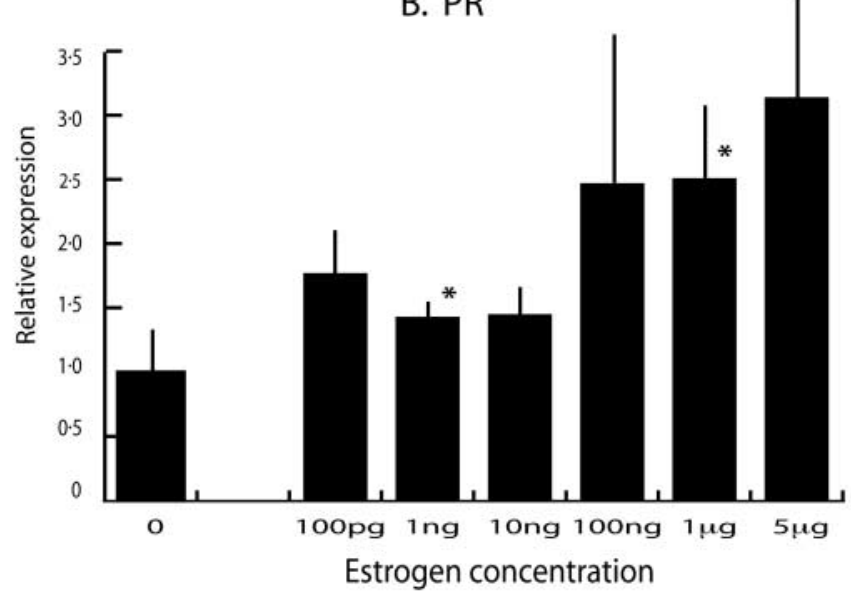

\section{Estrogen concentration-dependent correlation between peak Pax-2 protein and Wnt-4 mRNA expression.}

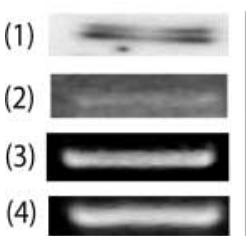

OVX
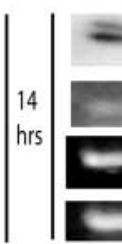
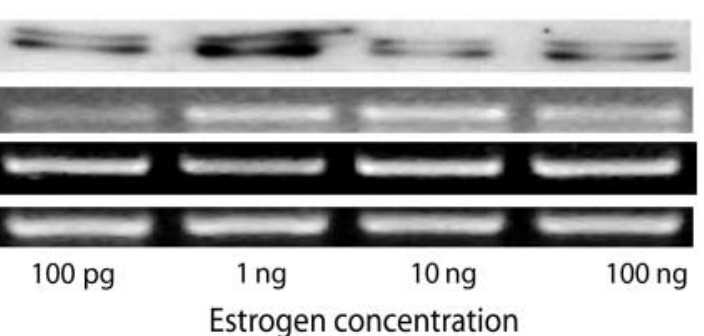

\section{Estrogen concentration}

Figure 7 Estrogen dose-responsiveness of Pax-2, PR, and Wnt-4 expression. (A) Pax-2 mRNA. Error bars represent S.D. and response to the $1 \mathrm{ng}$ estrogen response $\left(^{*}\right)$ was significantly greater than the response to 10 ng at $P<0 \cdot 05$, Student's $t$-test. (B) PR mRNA. Response to the $1 \mu$ g estrogen response $\left({ }^{*}\right)$ was significantly greater than the $1 \mathrm{ng}$ response at $P<0 \cdot 05$, Student's $t$-test. For $(\mathrm{A})$ and $(\mathrm{B})$, ovariectomized animals were treated with the noted doses of estrogen by subcutaneous injection and killed after $8 \mathrm{~h}$ to avoid, in the case of Pax-2, possible later masking of estrogen stimulation by the Pax- 2 mRNA peak at $12 \mathrm{~h}$. Two sets of animals were treated and three reverse transcription reactions analyzed for each dose. Relative expression levels were calculated by normalizing values from hormone treated animals to the value from untreated, ovariectomized mice. (C) Pax-2 protein vs Wnt-4 mRNA. Ovariectomized animals were treated with the noted estrogen doses for $14 \mathrm{~h}$ to allow for protein loss, followed by expression after the increase in Pax-2 transcript level at $12 \mathrm{~h}$. A set of three animals per dose was used. Results are representative of two WIB experiments and, for mRNA, two reverse transcription reactions. (1) Pax-2 WIB, nuclear protein. RT-PCR; (2) Wnt-4; (3) PR; (4) GAPDH, loading control. 
Table 2 Estrogen and progesterone-relevant regulatory motifs in the Pax-2 gene

\begin{tabular}{|c|c|c|c|c|c|c|c|}
\hline \multirow{2}{*}{ Region } & \multirow[t]{2}{*}{ Size (bp) } & \multicolumn{2}{|l|}{ ERE } & \multirow[t]{2}{*}{ SP-1 } & \multirow[t]{2}{*}{ AP-1 } & \multicolumn{2}{|l|}{ PRE } \\
\hline & & Full & Half & & & Full & Half \\
\hline $5^{\prime}$ UTR & 2000 & 0 & 4 & 6 & 1 & 0 & 3 \\
\hline Exon & 1221 & 0 & 8 & 4 & 0 & 0 & 3 \\
\hline Intron & 77373 & 12 & 316 & 96 & 22 & 1 & 159 \\
\hline $3^{\prime}$ UTR & 2000 & 0 & 4 & 2 & 1 & 0 & 1 \\
\hline
\end{tabular}

Pax-2 was analyzed for ERE. SP-1 and AP-1 motifs were included in this analysis because proteins recognizing these sites can bind liganded estrogen receptors and confer estrogen responsiveness to a gene (Hall et al. 2001, Petz et al. 2002). No EREs were found in the Pax-2 5'UTR; however, genes with GC-rich promoters, such as Pax-2, can be activated by estrogen in the absence of EREs by an estrogen/ER $\alpha$-Sp1 complex binding to a ERE half-sites (Stayner et al. 1998). Such genes typically have one or more SP-1 motifs in their 5'UTR; the Pax-2 5'UTR contained six. Activation can also occur via estrogen/ER $\alpha$-Fos-Jun complexes that bind to AP-1 sites, 24 of which were found primarily in downstream, intronic sites. Intronic sites were also rich in other relevant regulatory motifs; 12 full EREs with perfect or near-perfect palindromes and 332 half motifs were discovered, all but nine of the latter within introns. One hundred and eight SP-1 motifs were found, of which only five were in exons and 18 were in the $3^{\prime}$ UTR. One intronic progesterone receptor responsive element was found along with 166 halfsites, most intronic.

nucleus (Meyer et al. 2006). While in toto, the mammalian estrous cycle spans days and therefore, far exceeds the duration of the aforementioned cycles, it is nevertheless comprised of shorter elements (stages) such that during a single cycle, responsive tissues such as the mammary gland are subject to multiple timing regimes. With this in mind, it was heuristic to imagine that the pulse of estrogen in proestrus activates responses that are common to delays in the aforementioned shorter cycles and to analyze the delays in proestrus in terms of molecular mechanisms that operate in these betterunderstood systems.

The UPS is known to mediate estrogen-stimulated downregulation of the estrogen receptor in in vitro systems; however, this has not previously been demonstrated in vivo in an ovarian target tissue (El Khissiin \& Leclercq 1999). PS-341 caused the rapid (within 1-2 h) build-up of nuclear $\mathrm{ER} \alpha, \mathrm{PR}$, and Pax -2 proteins with a slower, but similar effect on cytoplasmic counterparts (Fig. 2). Together, these results demonstrated that estrogen-induced degradation of Pax-2, $\mathrm{PR}$ and $\mathrm{ER} \alpha$ was proteasome-dependent. The delays in expression caused by the turnover of each protein varied indicating that rates of proteasomal degradation were subject to independent regulation. Supporting a role for UPS action, a significant increase in proteasome chymotryptic activity was detected during proestrus coinciding with increased turnover of the three transcription factors in that stage. Taken together, these results indicate that estrogen-stimulated protein degradation via the UPS is the most likely explanation for the depletion of mammary gland $\mathrm{ER} \alpha, \mathrm{PR}$, and $\mathrm{Pax}-2$ during proestrus. These results are consistent with time-delay mechanisms in circadian systems and lead us to conclude that the UPS is an important element of a time-delay system in the mammary gland.

Negative transcription/translation feedback loops, in which a gene product directly or indirectly inhibits its own expression, are the hallmark of molecular time-delay systems (Van Gelder et al. 2003). The loss and restoration of each of the three transcription factors nominally fit a pattern of self-inhibition as the degradation of pre-existing protein preceded its restoration (Fig. 2). Supporting the feedback inhibition hypothesis, in the estrogen time-course study peak transcription of Pax-2 and PR was correlated with maximum loss of cognate protein. The likelihood that estrogen naturally stimulates the same phenomenon during the estrous cycle is indicated by the fact that in proestrus, peak Pax -2 and PR transcription coincided with the lowest levels of cognate protein. Regarding molecular mechanisms of feedback inhibition, the $\mathrm{Pax}-2$ promoter has no consensus $\mathrm{Pax}-2$ binding sequences so inhibition is probably not due to direct binding of Pax-2 to its own promoter (Picker et al. 2002). Alternatively, feedback regulation could occur via a transcription factor controlled by Pax-2, specifically WT1, the Wilms tumor suppressor gene. WT1 is co-expressed with Pax-2 in mammary gland stem cells and Pax-2 transactivates the WT1 promoter, whereas WT1 represses Pax-2 expression (Ryan et al. 1995, Dehbi et al. 1996, Stayner et al. 1998, Silberstein et al. 2002). Consistent with an estrous cycle Pax-2/WT1 interaction, changes in the expression of WT1 isoforms were detected during proestrus (data not shown).

The mechanism(s) that trigger delayed ER $\alpha, \mathrm{PR}$, and Pax2 expression appear to be separate from those that govern the delay duration. For example, the onset of $\mathrm{Pax}-2, \mathrm{PR}$, and $\mathrm{ER} \alpha$ proteolysis in the nucleus (and possibly the cytoplasm) was synchronous or nearly so as the loss of all three proteins in the nucleus was nearly complete by $2 \mathrm{~h}$. This relatively rapid loss was consistent with UPS action and the common understanding that a primary UPS function is the sharp, negative regulation of transcription factor activity (Pickart 2004). In striking contrast to rapid nuclear decay, loss of Pax-2 and ER $\alpha$ in the cytoplasm took $10 \mathrm{~h}$ or more to reach a nadir. Focusing on Pax-2, this resulted in a long-duration delay that was dominant in that it, and not nuclear decay, determined the timing of apparent negative self-regulation of Pax-2 as well as the duration of the Wnt-4 transcriptional delay (Figs 2, 3 , and 6). This result indicates that cytoplasmic pathways govern the timing of the Pax-2 time-delay feedback 
mechanism. Furthermore, it indicates that adjustments to the timing of expression of genes such as Wnt-4 originate in the cytoplasm as well. The molecular basis for long-duration delays in circadian clocks was a mystery until very recently when a cytoplasm-based mechanism was shown to depend on the time constant of dissociation of PER and TIM heterodimers prior to their entry into the nucleus (Dunlap 2006, Meyer et al. 2006). The cytoplasmic locus of the longduration Pax-2/Wnt-4 timing system therefore supports our hypothesis that molecular mechanisms found in classic circadian time-delay systems also operate in the mammary gland in response to the estrous cycle estrogen pulse.

At the cellular level, all known biological time-delays involve proteins, such as PER and TIM in circadian clocks, which serve dedicated timing functions (Van Gelder et al. 2003). The discovery that Pax-2 ablation eliminated the $18-\mathrm{h}$ delay in estrogen-induced Wnt-4 expression is evidence that under the special conditions of pulsed estrogen, delay is a Pax-2 function and retardation of Wnt-4 expression is a Pax-2 phenotype in the mammary gland. There is evidence that Pax-2 normally delays Wnt-4 expression in proestrus since, if it did not, the estrogen surge should have rapidly induced the growth factor causing peak expression in proestrus. In fact, Wnt-4 peaked not in proestrus but during estrus, consistent with an expression delay of roughly $18 \mathrm{~h}$ (Fig. 5). As a putative component of an estrogen-driven timing system, Pax-2 was predicted to be responsive to changing estrogen concentrations. This was initially indicated by the peak in Pax-2 mRNA in proestrus mirroring estrogen-induced PR mRNA; dose-response experiments directly confirmed Pax-2 estrogen responsiveness (Figs 1, 7). Importantly, the latter studies supported a regulatory link with Wnt-4 expression as concentrations of estrogen that maximally induced Pax-2 protein after a delay also maximally elevated steady-state Wnt-4 mRNA. It has been suggested that dispersed ERE motifs in the $P R$ gene enable fine-tuned regulation of PR expression by titering estrogen concentration and converting this information into timing signals during the estrous cycle (Kraus et al. 1994). A search for EREs in the Pax- 2 gene revealed multiple dispersed motifs that would enable Pax-2 to directly monitor estrogen flux by detecting changing concentrations of liganded ER $\alpha$. In light of its Wnt-4 delaying function and estrogen responsiveness, we conclude that Pax-2 is a strong candidate for an estrous cycle-specific delay or timing gene, a function not previously imagined for any gene in an ovarian target tissue.

Concerning the biological relevance of delays, the nurturing of newborns is critical to species survival; molecular adaptations that anticipated lactation by optimizing mammary secretory development during the estrous cycle would therefore not be surprising. Cellular responses to estrogen are limited by $\mathrm{ER} \alpha$ concentration and the strongest estrogen responses are therefore expected when new receptor protein appears in synchrony with elevated estrogen (Webb et al. 1992). A mammary gland timing system that both induced new ER $\alpha$ and delayed its expression until estrus (ca $24 \mathrm{~h})$, could optimize estrogen action by coordinating the expression of new receptor with the estrogen rebound in that stage. Delayed expression of PR and Pax-2 was also consistent with the optimization hypothesis. RANKL, a factor necessary for development of milk secreting alveoli and an indicator of progesterone action, was expressed during estrus where it marked the coincident appearance of newly synthesized PR and surging progesterone. The optimizing effect of the Wnt-4 delay would be twofold, prevention of premature ductal development in proestrus and increased concentration of Wnt-4 in estrus, both of which should enhance secondary ductal branching providing a more extensive framework on which to develop alveoli. For each of the three transcription factors then, a biologically relevant reason for delaying their expression after the estrogen surge in proestrus can be offered: retarding expression should enhance secretory development.

Considering the molecular data and the arguments for biological relevance, we conclude that there is good evidence for an estrogen-activated, estrous cycle-responsive timing system in the mammary gland whose function is to interpret a relatively crude time signal, the estrogen pulse in proestrus, and locally temporalize gene expression to optimize preparations for pregnancy. Since feedback regulation of transcription is a central feature of most cellular functions, it has been posited that delay-regulated ultradian transcriptional cycles should be common (Monk 2003). Nevertheless, few have been observed, no doubt due to their transience and the conditions necessary for their detection, which include synchronous cell populations and measurements with high temporal resolution. In this light, we suggest that the estrogen pulse in proestrus synchronizes cells and gene expression and our staged sampling fortuitously captured 'snapshots' of the downstream delays. The relatively high temporal resolution of the time-course studies in a system that had been artificially synchronized by estrogen injection also captured the delays enabling more detailed analysis. To resolve the temporal boundaries of this timing system during the estrous cycle, will therefore require similar high-resolution analysis of the diestrus to estrus interval.

To summarize, three lines of evidence support an estrous cycle responsive timing system in the mammary gland: (i) delays: delayed expression of $\mathrm{ER} \alpha, \mathrm{PR}$, and Pax-2 share molecular regulatory features with the classic circadian clock systems that include targeted proteolysis by proteasomes, feedback regulation, and a cytoplasmic locus for longduration delays; (ii) timing genes: Pax-2 displayed a unique Wnt-4 timing function; (iii) functionality: the timing of Wnt-4 and RANKL expression correlated with delayed expression of Pax -2 and $\mathrm{PR}$, and delayed $\mathrm{ER} \alpha$ expression correlated with rising systemic estrogen, all of which could optimize secretory development. Our preliminary results showing time-delays and proteasome activity in uterine tissue suggest that timing systems with properties similar to the mammary system are likely to operate in all ovarian target tissues. 
In conclusion, the analysis of ovarian target tissue responses to the estrous cycle has historically focused on genes governing developmental phenotypes during the different stages. Genes exhibiting temporal phenotypes, although well known in other time-delayed systems, have not previously been considered in this context. We now suggest that the complex repertoire of temporal responses in ovarian target tissues means that many genes with direct and indirect timing functions await discovery. This understanding offers a novel conceptual base from which to deepen our understanding of the molecular regulation of estrous cycle responsiveness in the mammary gland as well as in other ovarian target tissues.

\section{Acknowledgements}

The authors wish to thank Dr Gregory Dressler for making Pax2 null mouse embryos available. We are grateful to Drs Dana Ault-Riche, Paul Edwards, Lindsay Hinck, Karpagam Srinivasan, and Ms Phyllis Strickland for helpful comments. The authors declare that there is no conflict of interest that would prejudice the impartiality of this scientific work.

\section{Funding}

This work was supported by NIH grant CA091996 to G B S.

\section{References}

Alarid ET, Bakopoulos N \& Solodin N 1999 Proteasome-mediated proteolysis of estrogen receptor: a novel component in autologous downregulation. Molecular Endocrinology 13 1522-1534.

Atwood CS, Ikeda M \& Vonderhaar BK 1995 Involution of mouse mammary glands in whole organ culture: a model for studying programmed cell death. Biochemical and Biophysical Research Communications 207 860-867.

Brennan KR \& Brown AM 2004 Wnt proteins in mammary development and cancer. Journal of Mammary Gland Biology and Neoplasia 9 119-131.

Brisken C, Heineman A, Chavarria T, Elenbaas B, Tan J, Dey SK, McMahon JA, McMahon AP \& Weinberg RA 2000 Essential function of Wnt-4 in mammary gland development downstream of progesterone signaling. Genes and Development 14 650-654.

Brisken C, Ayyannan A, Nguyen C, Heineman A, Reinhardt F, Tan J, Dey SK, Dotto GP, Weinberg RA \& Jan T 2002 IGF-2 is a mediator of prolactininduced morphogenesis in the breast. Developmental Cell 3 877-887.

Bronson FH \& Desjardins C 1974 Circulating concentrations of FSH, LH, estradiol, and progesterone associated with acute, male-induced puberty in female mice. Endocrinology 94 1658-1668.

Cai Y, Lechner MS, Nihalani D, Prindle MJ, Holzman LB \& Dressler GR 2002 Phosphorylation of Pax2 by the c-Jun N-terminal kinase and enhanced Pax2-dependent transcription activation. Journal of Biological Chemistry 277 1217-1222.

Champlin AK, Dorr DL \& Gates AH 1973 Determining the stage of the estrous cycle in the mouse by the appearance of the vagina. Biology of Reproduction 8 491-494.

Cheng G, Li Y, Omoto Y, Wang Y, Berg T, Nord M, Vihko P, Warner M, Piao YS \& Gustafsson JA 2005 Differential regulation of estrogen receptor (ER)alpha and ERbeta in primate mammary gland. Journal of Clinical Endocrinology and Metabolism 90 435-444.
Cohen PE, Zhu L \& Pollard JW 1997 Absence of colony stimulating factor-1 in osteopetrotic (csfmop/csfmop) mice disrupts estrous cycles and ovulation. Biology of Reproduction 56 110-118.

Dehbi M, Ghahremani M, Lechner M, Dressler G \& Pelletier J 1996 The paired-box transcription factor, PAX2, positively modulates expression of the Wilms' tumor suppressor gene (WT1). Oncogene 13 447-453.

den Elzen N \& Pines J 2001 Cyclin A is destroyed in prometaphase and can delay chromosome alignment and anaphase. Journal of Cell Biology 153 121-136.

Don RH, Cox PT, Wainwright BJ, Baker K \& Mattick JS 1991 'Touchdown' PCR to circumvent spurious priming during gene amplification. Nucleic Acids Research 194008.

Dressler GR \& Douglass EC 1992 Pax-2 is a DNA-binding protein expressed in embryonic kidney and Wilms tumor. PNAS 89 1179-1183.

Dunlap JC 2006 Running a clock requires quality time together. Science 311 184-186.

Eide EJ, Woolf MF, Kang H, Woolf P, Hurst W, Camacho F, Vielhaber EL, Giovanni A \& Virshup DM 2005 Control of mammalian circadian rhythm by CKIepsilon-regulated proteasome-mediated PER2 degradation. Molecular and Cellular Biology 25 2795-2807.

El Khissiin A \& Leclercq G 1999 Implication of proteasome in estrogen receptor degradation. FEBS Letters 448 160-166.

Fata JE, Kong YY, Li J, Sasaki T, Irie-Sasaki J, Moorehead RA, Elliott R, Scully S, Voura EB, Lacey DL et al. 2000 The osteoclast differentiation factor osteoprotegerin-ligand is essential for mammary gland development. Cell 103 41-50.

Fata JE, Chaudhary V \& Khokha R 2001 Cellular turnover in the mammary gland is correlated with systemic levels of progesterone and not 17beta-estradiol during the estrous cycle. Biology of Reproduction 65 680-688.

Hall JM, Couse JF \& Korach KS 2001 The multifaceted mechanisms of estradiol and estrogen receptor signaling. Journal of Biological Chemistry 276 36869-36872.

Hilton TL \& Wang EH 2003 Transcription factor IID recruitment and Sp1 activation. Dual function of TAF1 in cyclin D1 transcription. Journal of Biological Chemistry 278 12992-13002.

Hirata H, Yoshiura S, Ohtsuka T, Bessho Y, Harada T, Yoshikawa K \& Kageyama R 2002 Oscillatory expression of the bHLH factor Hes1 regulated by a negative feedback loop. Science 298 840-843.

Horigome T, Ogata F, Golding TS \& Korach KS 1988 Estradiol-stimulated proteolytic cleavage of the estrogen receptor in mouse uterus. Endocrinology $1232540-2548$.

Hovey RC, Trott JF, Ginsburg E, Goldhar A, Sasaki MM, Fountain SJ, Sundararajan K \& Vonderhaar BK 2001 Transcriptional and spatiotemporal regulation of prolactin receptor mRNA and cooperativity with progesterone receptor function during ductal branch growth in the mammary gland. Developmental Dynamics 222 192-205.

Jablonka-Shariff A, Ravi S, Beltsos AN, Murphy LL \& Olson LM 1999 Abnormal estrous cyclicity after disruption of endothelial and inducible nitric oxide synthase in mice. Biology of Reproduction $\mathbf{6 1}$ 171-177.

Kraus WL, Montano MM \& Katzenellenbogen BS 1994 Identification of multiple, widely spaced estrogen-responsive regions in the rat progesterone receptor gene. Molecular Endocrinology 8 952-969.

Lange CA, Shen T \& Horwitz KB 2000 Phosphorylation of human progesterone receptors at serine- 294 by mitogen-activated protein kinase signals their degradation by the 26S proteasome. PNAS 97 1032-1037.

LeBlanc R, Catley LP, Hideshima T, Lentzsch S, Mitsiades CS, Mitsiades N, Neuberg D, Goloubeva O, Pien CS, Adams J et al. 2002 Proteasome inhibitor PS-341 inhibits human myeloma cell growth in vivo and prolongs survival in a murine model. Cancer Research 62 4996-5000.

Lee W, Mitchell P \& Tjian R 1987 Purified transcription factor AP-1 interacts with TPA-inducible enhancer elements. Cell 49 741-752.

Liu X, Robinson GW \& Hennighausen L 1996 Activation of Stat5a and Stat $5 \mathrm{~b}$ by tyrosine phosphorylation is tightly linked to mammary gland differentiation. Molecular Endocrinology 10 1496-1506.

Maulbecker CC \& Gruss P 1993 The oncogenic potential of Pax genes. EMBO Journal 12 2361-2367. 
McGowan CH 2003 Regulation of the eukaryotic cell cycle. Progress Cell Cycle Research 5 1-4.

Meyer P, Saez L \& Young MW 2006 PER-TIM interactions in living Drosophila cells: an interval timer for the circadian clock. Science 311 226-229.

Michael SD 1976 Plasma prolactin and progesterone during the estrous cycle in the mouse. Proceedings of the Society for Experimental Biology and Medicine 153 254-257.

Monk NA 2003 Oscillatory expression of Hes1, p53, and NF-kappaB driven by transcriptional time delays. Current Biology 13 1409-1413.

Nandi S 1959 Hormonal control of mammogenesis and lactogenesis in the C3H/He Crgl Mouse. Zoology 65 1-128.

Nawaz Z \& O'Malley BW 2004 Urban renewal in the nucleus: is protein turnover by proteasomes absolutely required for nuclear receptor-regulated transcription? Molecular Endocrinology 18 493-499.

Nelson JF, Felicio LS, Osterburg HH \& Finch CE 1981 Altered profiles of estradiol and progesterone associated with prolonged estrous cycles and persistent vaginal cornification in aging C57BL/6J mice. Biology of Reproduction 24 784-794.

Nelson JF, Felicio LS, Randall PK, Sims C \& Finch CE 1982 A longitudinal study of estrous cyclicity in aging C57BL/6J mice: I. Cycle frequency, length and vaginal cytology. Biology of Reproduction 27 327-339.

Nelson CC, Hendy SC, Shukin RJ, Cheng H, Bruchovsky N, Koop BF \& Rennie PS 1999 Determinants of DNA sequence specificity of the androgen, progesterone, and glucocorticoid receptors: evidence for differential steroid receptor response elements. Molecular Endocrinology 13 2090-2107.

Petz LN \& Nardulli AM 2000 Sp1 binding sites and an estrogen response element half-site are involved in regulation of the human progesterone receptor A promoter. Molecular Endocrinology 14 972-985.

Petz LN, Ziegler YS, Loven MA \& Nardulli AM 2002 Estrogen receptor alpha and activating protein-1 mediate estrogen responsiveness of the progesterone receptor gene in MCF-7 breast cancer cells. Endocrinology 143 4583-4591.

Pickart CM 2004 Back to the future with ubiquitin. Cell 116 181-190.

Picker A, Scholpp S, Bohli H, Takeda H \& Brand M 2002 A novel positive transcriptional feedback loop in midbrain-hindbrain boundary development is revealed through analysis of the zebrafish pax2.1 promoter in transgenic lines. Development 129 3227-3239.

Pourquie O \& Goldbeter A 2003 Segmentation clock: insights from computational models. Current Biology 13 R632-R634.

Robinson GW, McKnight RA, Smith GH \& Hennighausen L 1995 Mammary epithelial cells undergo secretory differentiation in cycling virgins but require pregnancy for the establishment of terminal differentiation. Development 121 2079-2090.

Ryan KD \& Schwartz NB 1980 Changes in serum hormone levels associated with male-induced ovulation in group-housed adult female mice. Endocrinology 106 959-966.

Ryan G, Steele-Perkins V, Morris JF, Rauscher FJ, 3rd. \& Dressler GR 1995 Repression of Pax-2 by WT1 during normal kidney development. Development $121867-875$.
Sathya G, Li W, Klinge CM, Anolik JH, Hilf R \& Bambara RA 1997 Effects of multiple estrogen responsive elements, their spacing, and location on estrogen response of reporter genes. Molecular Endocrinology 11 1994-2003.

Schedin P, Mitrenga T \& Kaeck M 2000 Estrous cycle regulation of mammary epithelial cell proliferation, differentiation, and death in the Sprague-Dawley rat: a model for investigating the role of estrous cycling in mammary carcinogenesis. Journal of Mammary Gland Biology and Neoplasia 5 211-225.

Schuchard M, Landers JP, Sandhu NP \& Spelsberg TC 1993 Steroid hormone regulation of nuclear proto-oncogenes. Endocrine Reviews 14 659-669.

Silberstein GB 2001 Postnatal mammary gland morphogenesis. Microscopy Research and Technique 52 155-162.

Silberstein GB, Dressler GR \& Van Horn K 2002 Expression of the PAX2 oncogene in human breast cancer and its role in progesterone-dependent mammary growth. Oncogene 21 1009-1016.

Stayner CK, Cunliffe HE, Ward TA \& Eccles MR 1998 Cloning and characterization of the human PAX2 promoter. Journal of Biological Chemistry 273 25472-25479.

Stuart E \& Gruss P 1996 PAX: Developmental control genes in cell growth and differentiation. Cell Growth and Differentiation 7 405-412.

Tsai HW, Katzenellenbogen JA, Katzenellenbogen BS \& Shupnik MA 2004 Protein kinase A activation of estrogen receptor alpha transcription does not require proteasome activity and protects the receptor from ligand-mediated degradation. Endocrinology 145 2730-2738.

Van Gelder RN, Herzog ED, Schwartz WJ \& Taghert PH 2003 Circadian rhythms: in the loop at last. Science 300 1534-1535.

Walmer DK, Wrona MA, Hughes CL \& Nelson KG 1992 Lactoferrin expression in the mouse reproductive tract during the natural estrous cycle: correlation with circulating estradiol and progesterone. Endocrinology 131 1458-1466.

Webb P, Lopez GN, Greene GL, Baxter JD \& Kushner PJ 1992 The limits of the cellular capacity to mediate an estrogen response. Molecular Endocrinology 6 157-167.

Weber-Hall SJ, Phippard DJ, Niemeyer CC \& Dale TC 1994 Developmental and hormonal regulation of Wnt gene expression in the mouse mammary gland. Differentiation 57 205-214

Xiong S, Chirala SS \& Wakil SJ 2000 Sterol regulation of human fatty acid synthase promoter I requires nuclear factor-Y- and Sp-1-binding sites. PNAS 97 3948-3953.

Young LJT 2000 The cleared mammary fat pad and the transplantation of mammary gland morphological structures and cells. In Methods in Mammary Gland Biology and Breast Cancer Research, pp 67-74. Eds MM Ip \& BB Asch. New York, NY, USA: Kluwer Academic/Plenum.

Received in final form 17 April 2006

Accepted 20 April 2006

Made available online as an Accepted Preprint

3 May 2006 